\title{
Study on Shaanxi Local Dialect and Its Cultural Representation
}

\author{
Li Tie \\ Xi'an University,School of Foreign Studies,Shaaxi Xi'an 710065
}

Keywords: Shaanxi dialect; Cultural representation; Jia Pingwa literary works; Translation teaching

\begin{abstract}
Shaanxi cultural dialect is very distinctive and is one of the most important manifestations of Shaanxi's unique culture. However, due to the geographical differences, Shaanxi dialects are not the same way each region. Based on the analysis of the regional and historical culture in Shaanxi province and the translation of works written by Mr. Jia Pingwa, this paper explores the difficulties and challenges in the process of English translation of Shaanxi regional culture-loaded dialect. From the perspective of pedagogy, local culture has the characteristics of "living world" as Husserl can well integrate scientific and cultural knowledge and life details. Therefore, in the sense of life-oriented education, teaching cultural translation for English majors to cultivate the ability of logical thinking has a strong guiding significance and application value.

There have been verse like this description of Shaanxi, " it was the cultural and military resorts in Zhou, Qin, Han and Tang dynasties, the sound of bells and drums was heard in the sky." In this land the splendid civilization of the Han and Tang dynasties was nurtured. At the same time a large number of excellent writers, such as Chen Zhonglu, Lu Yao, Jia Pingwa, have been brought up. Among them, Mr. Jia Pingwa also has a long reputation due to his works winning numerous international awards. This paper mainly analyzes Jia Pingwa's literary works and its cultural manifestation.
\end{abstract}

\section{Introduction}

The Shaanxi Historical and Cultural Impact on Shaanxi Dialects. As one of the cradles of the Chinese nation, Shaanxi has rich cultural connotations. From the Shang and Zhou dynasties to the prosperity of the Han and Tang dynasties, the Song, Yuan, Ming and Qing Dynasties to the founding of new China, the Shaanxi culture with unique charm shone in the world. Its uniqueness is mainly reflected in its integrity, supremacy and revolutionary nature. These characteristics have a far-reaching impact on the formation of Shaanxi dialects. The main features are as follows:

First, the integrity of Shaanxi's history and culture is the cornerstone of the development of Shaanxi dialects. Shaanxi has a long history, fully demonstrating its unique cultural heritage. After a generation of inheritance, Shaanxi has absorbed a large number of alien cultures. While embodying its own inclusiveness, Shaanxi has laid a solid foundation for the formation of Shaanxi dialects. Walking in today's capital city of Xi'an in Shaanxi, it is not difficult to find that this is a large and inclusive city.

Second, the supremacy of Shaanxi's history and culture has made Shaanxi dialects unique. Shaanxi, a province that has long been the political, economic and cultural center of our country, undoubtedly represents the essence of the Chinese civilization. Its culture also fully reflects the long and splendid Chinese history and the extensive and profound Chinese ancient civilization. This piece of unique land gave birth to a unique Shaanxi dialect. Shaanxi dialects can be roughly divided into southern Shaanxi dialect, Guanzhong dialect and northern Shaanxi dialect. The three dialects are slightly different and boast for their own characteristics. The supreme nature of Shaanxi history and culture has created the present Shaanxi dialect.

Third, the revolutionary spirit contained in Shaanxi history and culture is a source of endless living in Shaanxi dialects. Most of the Communist revolutionaries of that year lived in the cave here for more than a decade, and Yan'an and Wuqi were all revolutionary sites. Shaanxi writers are also keen on writing the revolutionary spirit of the masses of the people, which adds another trace of revolutionary spirit to Shaanxi dialects, such as works by Jia Pingwa and Chen Zhongshi.

Shaanxi, after thousands of years of changing circumstances, innumerable dynasties and the 
erosion of the trend of the new era, its unique cultural connotation is still developing and circulating. Walking in the streets of Shaanxi, listening to the unique Shaanxi dialect with a unique Shaanxi culture, will all inevitably make people feel the rich history of Shaanxi. Of course, in addition to having an outstanding history and culture, Shaanxi also has a unique geographical advantage. These geographical locations also affect the development of regional dialects in Shaanxi to a certain extent.

The Significance of Cultural Translation Teaching to the Cultivation of English Majors' Competence. English major students have long been exposed to the main knowledge, inclined to the application level of knowledge. According to the different teaching objectives, English teaching basic guide is roughly divided into two categories, "specialized English teaching" and "general-purpose English teaching", but are essentially "language skills teaching" based on English language and intercultural communication. For such English majors who have long accepted different cultures and different kinds of thinking knowledge, successful "speculative process" can not be achieved without the ability of some logical thinking to carry out critical transformation and acceptance of specific knowledge. ${ }^{[1]}$ Local dialect culture presents the diversified value orientation of "harmony between man and nature" and "harmony but different" in Chinese context. Teaching by means of the differences in cultural connotation of local dialects can help guide students to "critically" the cultural differences between China and the West.

English language majors will inevitably have poor educational psychology such as "westernization" and "worship of nature" in the process of accepting language knowledge and cultural metaphors of English background. An individual should have the consciousness of "cultural self-confidence" and "cultural self-consciousness" first in forming a complete ability of speculative ability. ${ }^{[2]}$ Only by establishing such a sense of cultural pride can it be realized in the complicated cross-cultural communication with the outside world of the active dialogue in order to carry forward the traditional Chinese culture and enhance the soft power of Chinese culture to provide the basis for the spread. Chinese local language culture has far-reaching and profound connotation and extensive influence. It has very representative meaning in the aspect of material carrier of tea culture, practical carrier and metaphysical value system. From this cultural self-confidence, literary translation is conducive to cultivating students' cultural self-confidence.

\section{The Influence of Shaanxi Geography on Shaanxi Dialects}

Shaanxi is mainly divided into Guanzhong region, northern Shaanxi region and southern Shaanxi region, so the dialect, northern Shaanxi dialect, and southern Shaanxi dialect.

There have been verse describing the Loess Plateau: "Yellow sky, thick earth and a long river, crisscross network of ravines with frenzy of wind and rain;Through ancient years the cypress like a shaft in Hsuan-yuen park, blue tendons stand upright." And grown in the Loess Plateau, Northern Shaanxi people speak their northern Shaanxi dialect with a unique charm. In addition to the unique geographical location of the Loess Plateau, the reason lies in the fact that the north of Shaanxi is a diverse area with many nationalities, ethnic cultures blend together here, thus forming a unique traditional northern Shaanxi culture and the northern Shaanxi dialect. Taking folk songs "Xin Tian You" in Northern Shaanxi as an example, they describes the unique dialect charm of northern Shaanxi and play an extremely important role in the study of dialects. Guanzhong, flat and broad and flat, has always been the battleground of the military, bears the reputation for extending 800 miles in Qinchuan. Because of the topography and the natural environment different from that of the southern Shaanxi \& northern Shaanxi, the dialects of Guanzhong differ from those of the other two dialects. Meanwhile the dialects of Guanzhong also have branches. Guanzhong dialect, also known as the Central Plains Mandarin, in some ancient Chinese dynasties, ever served as the Chinese official language, which is inseparable from the unique geographical location of the area. Therefore, Guanzhong dialect plays an important role in the study of Shaanxi dialect. Southern Shaanxi, the climate being comfortable and humid, is an important source of Han culture. Here, occurred the ever-changing historical period: Liu Bang proclaimed himself king; Liu Bei left the 
legendary history of southern Shaanxi. Since southern Shaanxi is close to the Bashu region, the dialects of southern Shaanxi mainly include Jingchu dialects and Bashu dialects. The unique dialects here are also unmatched elsewhere. ${ }^{[3]}$

\section{The Specific Manifestation of Shaanxi Dialect}

After analyzing the history and culture and the geographical advantages of Shaanxi, the uniqueness of Shaanxi dialects is easily reflected. Different from Mandarin, Shaanxi dialect involves in a unique charm. E.g:

\begin{tabular}{|c|c|c|}
\hline Shaanxi dialects & Mandarin & English \\
\hline 你日弄人呢么? & 你在跟我开玩笑吧? & Are you kidding me? \\
\hline 么肆么肆! & 没关系! & Don"t worry. \\
\hline 包年穿。 & 不要乱说。 & Shut up! \\
\hline 厄贼! & 天呐! & What a hell! \\
\hline 么问题。 & 没问题。 & I am sure. \\
\hline
\end{tabular}

These a bit hard-tongued words for foreigners, are contrarily smoothly read in the mouth of Shaanxi people with a unique flavor. With the passage of time, Shaanxi dialects have drawn more and more attention. Especially since the transformation of China's reform and opening up in 1992, in order to enrich the spiritual life of the masses and to bring China to the world, literature of all kinds has received unprecedented attention. The dialect literary works, as one of the important branches, is worth studying. Shaanxi dialect is the carrier of local culture and vice versa, Shaanxi local culture demonstrate itself most vividly in dialects.

\section{The Local Dialects of Shaanxi in Jia Pingwa 's Literary Works}

Jia Pingwa was born in Danfeng County, Shaanxi Province. Jia Pingwa is one of the most influential literary figures in contemporary literary circles in China. He is one of the most rebellious, creative and widely influential writers in the world today, as well as a well-known Chinese contemporary writer that can enter the annals of Chinese and world literature. He is known as a wizard. His masterpieces include "Shaanxi Opera", "Happy Dreams", "The Lantern Bearer", "Traces of Love". The other two novels Turbulence and Ruined City written by Jia Pingwa, were translated into many versions in different languages, among which the provincial color of Jia Pingwa's "Shangzhou" novels are distinguished. The native language and native culture go through the whole novel. So, the challenges for the translator, is to know the resource text culture and language background. Howard Goldblatt, a prestigious American translator, is the most famous translator of Chinese literature in the world. His translations are rigorous and stressful. He has translated a bunch of Chinese writers including Xiao Hong, Chen Ruoxi, Bai Xianyong, Li Ang, Zhang Jie, Yang Jiang, Feng Jicai, Gu Hua, Jia Pingwa, Li Rui, Liu Heng, Su Tong, Lao Gui, Wang Shuo, Mo Yan, Hong Ying, Zhu Tianwen, Zhu Tianxin and Jiang Rong, totally more than 20 famous writers and more than 40 pieces of works. His translations have dyed Chinese literature the color of contemporary British and American literature, and have also made the local literary works well accepted and appreciated by more and more foreign readers.

A concealed achievement of "Ruined City" made the generalized social structure at the daily life level enter Chinese contemporary novels. ${ }^{[4]}$ Jia Pingwa has revived a series of basic life scenarios and basic emotional modes in the novel, so that readers are supposed to feel the world's and life's pulses and rhetoric. The figures and happenings are not only ancients, but they are still asleep in our hearts and our genes. Readers' anonymous emotion, joy and grievances at the bottom of their heart are aroused in the "Ruined City", suddenly enlightened that the original is the same with all ages. The novel's main character Jin dog in Turbulence, after returning home to join the army, work as the news reporter, resign and run on the business, lived a few ups and downs of life, gradually with his life experience unfolding a miniature of Shangzhou. ${ }^{[5]}$ That was a true social picture in the last decade or so of the last century. At that time, a key word of reform did constantly affect the thinking and mentality of Chinese political leaders and ordinary people. ${ }^{[6]}$ In his translation of these two 
works, Howard Goldblatt said that it was very difficult. The final publication of "Ruined City" in the United States benefited from hundreds of communications between two masters at home and abroad. In his works, the culture-loaded local vocabulary of the belief of marriage and funeral, the ancient Chinese function words are all reproduced in English translation works because of "keeping original Shaanxi flavor."

Jia Pingwa applied a lot of Shaanxi dialects in his works. For example, “婆娘”, “长虫尻子”,“瓷 了一会儿”,“日娘捣老子”,“把什么事都支应了”,“长得老面”, “赶集”,“黄花女子” and so on. Under the translation of Howard Goldblatt, most of these uniquely attractive Shaanxi dialects have adopted the strategy of foreignization. For example, "庄之蝶" is not translated as "Butterfly" but "Zhuang Zhidie (the main character in the novel;a famous writer; one of the 'Famous Four') with annotation plus Pingyin method to explain before translation; "不静岗" translated as "Restless Hill"; "泼烦"translated as" in search of a little recreation "and so on. Actually in China, sometimes people living in different regions even have no idea of a food item which has local color of another region, let alone people in other countries. ${ }^{[7]}$ Goldblatt's translation is definitely profound under the guidance of "Overseas Promotion of Chinese Literature".

\section{Summary}

Shaanxi culture is broad and profound, which subtly affects people from generation to generation. Shaanxi culture increasingly develops in the process of dissemination. As an inseparable part of Shaanxi culture, Shaanxi local dialect has far-reaching significance in its perfection and dissemination. The study of the translation of Shaanxi local dialect makes its readers better understand Shaanxi culture, so as to understand Shaanxi regional dialect culture more deeply, and finally make Shaanxi culture embrace the world.

In addition the significance of native culture translation teaching in cultivating students' professional ability of thinking is that it helps to improve students' ability to think critically, helps to systematically shape students "logical thinking ability, and helps cultivate students" cultural self-confidence. The main principle of cultivating students' ability of speculative discrimination based on cultural translation teaching lies in the principle of cultural comparison and the principle of open teaching. Based on culture translation teaching of English majors' ability, we can try to develop a combination of English for specific purposes and English as a common training strategy or living teaching strategy.

\section{Acknowledgement}

Fund Project: Shaanxi Provincial Social Science Fund Project"A Study on the Soft Power of Shaanxi Local Dialects through Cross-cultural Translation under the Belt and Road Initiative Project" Number: 2017K025

\section{References}

[1] Xiao-Ming Pan. Improve Students' Intercultural Communicative Ability in English Teaching [EB/OL]. http://www. blogworld. Com.cn,2005-06.

[2] Yue-Di Liu. Between "Textual Intersection" and "Intersubjectivity" - On the Intersectionality between Literary Activities[J]. Journal of Research on Theory of Literature and Art, 2005(4):64.

[3] Qi-Meng Du. An Analysis of the English Version of Turbulence from Lefevere's Manipulation Theory[D]. Beijing foreign language university, 2016.

[4] Ping-Wa Jia.Ruied City [M]. Beijing: Beijing Publishing Corporation, 2013.

[5] Ping-Wa Jia.Turbulence [M]. Guangzhou: Guangzhou Publishing Corporation, 2017.

[6] Howard Goldblatt. Turbulence [M]. University of Oklahoma Press:Norman,2016.

[7] Howard Goldblatt. Ruined City [M].Louisiana State University Press:Baton Rouge and London, 1991. 